Ivan JOKSIC, $\mathrm{PhD}^{*}$

Faculty of Law for Commerce and Judiciary

University Business Academy, Novi Sad

Doi: $10.5937 /$ bezbednost $1801068 \mathrm{~J}$

UDK: 614.253.83:347.12

Pregledni naučni rad

Primljen: 27. 11. 2017. godine

Datum prihvatanja: 22. 06. 2018. godine

\title{
Determining the legal liability in the cases of adverse outcomes of medical treatment (medical error)
}

\begin{abstract}
The profession of a medical professional (physician) includes providing medical assistance to patients, thereby allowing for the alleviation of consequences to their aggravated health condition. The medical profession is associated with many risks which the workers and the institutions providing such assistance are exposed to. It is not rare that physicians face or become involved in legal proceedings for the compensation of damages arising from the occurrence of medical errors. For these reasons, the aim of this study is the analysis of cases where there has been a medical error, and the ways of determining the physicians' liability. The data on the medical error cases were collected owing to the direct experience of the author of this study, who took part in legal proceedings as expert adviser. The data were also collected through the entry/exit tests taken by physicians within a course accredited by the Serbian Medical Chamber*. The collected material was processed using several methods. The results showed that the failure to follow procedures at both the proactive and reactive level contributes to the occurrence of medical errors. This research has shown the extent to which medical errors result in legal proceedings. It also points to the lack of knowledge on the part of physicians when it comes to the legal aspects of medical error.
\end{abstract}

Key words: medical error, patient, damages, legal proceedings, legal property claim, testing

*The paper is based on research findings in the course entitled: "The process of determining the professional liabilities in the cases of adverse outcomes of the medical treatment (medical error)". The course was approved by the Serbian Medical Chamber No 153-02-1979/2014-01 of 18th August, 2014. Email:ijoksic@hotmail.rs 


\section{Introduction}

The right to life and the right to health belong to the basic human rights, without which a range of other human rights can not be exercised. Excluding the permitted forms of restrictions of the human rights, we can mention the area where the life and health are most frequently compromised. These are the situations where the actions of people cause another person to be deprived of the right to life and health. If we take into account the risk that entails dealing with a certain profession, then we can mark the medical profession as a potentially dangerous zone which may cause a threat to human life and health. We should also bear in mind that these are mainly the actions which, as a rule, are harmful to the life and health of the patient due to the careless treatment of physicians.

The introduction of modern technical devices and similar gadgets in medicine has led to the increased spread of technologization in the relation between physicians and patients. Further development of medicine is directly conditioned by the use of sophisticated technical equipment. Owing to modern medical means, diagnosis is faster and more precise, and the treatment and rehabilitation are more efficient, more effective and safer (Cvetkovic, Nikolic, 2014: 352). However, the rapid development of technics and its use for medical purposes has not been able to exclude the possibility of the occurrence of medical errors. Therefore, in recent decades there are increasingly frequent cases in which the need for implementation of specific procedures to identify medical error has been emphasised. The borderline cases in which it came to medical errors are those when there was a fatality, i.e. patient's death or serious health damage. Therefore there has been a need to add external support to the relations between physicians and patients, in the form of legal norms of conduct, which would reduce mistrust (Lapcevic et al., 2001: 52).

In medicine, it has always been about health or sickness, i.e. life or death. Once upon the time the medical ethics contained an unwritten rule to be the sole arbiter in resolving these issues. The trust that patients used to have in their physician was at a high level. Hence the correctness of medical procedures was almost not within the jurisdiction of the courts (Radisic, 2004: 101). However, the profession of a physician is associated with many risks the physicians themselves are exposed to as well as the institutions where such assistance is provided. Hereby, first of all, we refer to the cases where the conscientious work of physicians is called into question by patients or members of their immediate family. 
In practice, the cases where physicians are drawn into civil legal procedures, i.e. litigations for compensation of damages are not that rare. The essence of initiating and conducting such proceedings concerns the review of options for compensation embodied in meeting the interests of patients as the injured party, i.e. prosecutors in the proceedings. The practice of the courts in the world is full of examples where there were litigations with the demanded damages expressed in millions. There is a large number of legal proceedings in which unscrupulous patients won the cases due to the lack of preparation by the defense of the defendant health care workers.

The lack of awareness of the need for more comprehensive regulation of the procedures and attitudes towards patients favored the negative outcomes of litigations to health workers. An additional reason for the unfavorable situation of health workers are sensationalist writing of certain media in which they are blamed for mistakes in advance. In this regard, the print media are dominant, publishing the premature and insufficiently verified information where health care workers are condemned in advance for the irregularities that have not been proven in the conducted legal proceedings.

\section{The concept and meaning of medical error}

The first findings of malpractice date from the time of the Old Babylonian Empire at the time of Hammurabi (1792-1750 BC). This ruler of the Old East is known for adopting the Code, which is one of the oldest legal documents. In this legal text there are provisions governing the liability of physicians for different actions. Thus, for example, the provision $\$ 218$ states the following: „If a physician inflicts a severe wound and kills a patient, or opens the eye of a patient and destroys the eye, his hands shall be cut off". In contrast to that, the provision $\$ 221$ states: "If a physician manages to cure patient's broken bone or soft weak parts, the patient shall give the physician five shekels of silver". There were findings of malpractice at the time of Hippocrates as a postulate "to help but without injury", as well as in the ancient Rome and in Imperial Russia.

The concept of the professional error appeared in the literature for the first time in the mid-nineteenth century. This phenomenon was identified by Semmelweis, who introduced the disinfection of hands, as a means to prevent the possible occurrence of a medical error. In the second half of the 20th century, German experts from Robert Koch Institute cite some interesting data related to the presence of medical errors in the work of German doctors. In fact, every year about 40,000 complaints for professional errors 
are filed in Germany, but about 12,000 of them are not be proven. It is useful to point out that in the United States, between 44,000 and 98,000 patients die as a result of medical errors (the data is used from the website: http://www.b92.net/zdravlje, 15 August, 2017).

The meaning of medical error was first described by German physician Rudolf Virchow in the second half of the nineteenth century, as a "violation of the generally recognized rules of the art of treatment, due to lack of necessary attention or prudence" (Radisic, 2009: 12). Such definition of medical error has experienced certain disputes along the lines of renaming it to negligent conduct of physicians, mistakes in applying treatments, serious or minor neglect of duties which a physician must abide etc. However, there are those who deny the possibility of the complete definition of medical error, primarily due to a variety of situations where it is necessary to assess the circumstances in which the treatment was conducted. It is therefore not possible to find a precise definition of medical error that would encompass all the aspects of mistreatment of physicians in carrying out their duties.

Taking into account the various definitions of its term, we can say that a medical error represents the actions of doctors violating the rules of the medical profession (contra legem artis), the regulations governing the medical industry and criminal legislation drafting the incriminating zone of certain offenses. Consequently the concept and meaning of a medical error may be based on medical and legal definitions.

The medical definition of medical error contains both the objective and subjective elements. Hence, a medical error can be considered as a violation of medical codes of practice (objective element) performed wrongly by the physicians in the context of their duties (subjective element).

The legal definition of medical error includes any actions of physicians (or failure to act) violating the applicable legal regulations. By this is meant a violation of special laws regulating the health industry and patient rights (health care users), as well as the violation of criminal regulations.

In terms of violations of health regulations, it is important to point out the content of certain provisions of Article 67 of the Law on Health Care (Law on Health Care of Serbia, "Official Gazette of the Republic of Serbia", No 107/05-106/15). This Article provides that, in the implementation of health care, the health institutions and private practices are obliged to apply scientifically proven, tested and safe medical technologies in the prevention, diagnostics, treatment and rehabilitation (paragraph 1). It also states that under health technologies is meant all medical methods and procedures that can be used in order to improve people's health, in the prevention, diagnosis and treatment of diseases, injuries and rehabilitation, which include safe, 
quality and effective medicines and medical devices, medical procedures and the conditions for the provision of health care (paragraph 2).

Given that the exercise of medical activities complementary to the rights of patients to which it is directed, and represent an important moment of the applicable provisions of the Law on Patients' Rights (Law on Patients' Rights, "Official Gazette of the Republic of Serbia", No 45/13). According to Article 3 of this law, the patient is guaranteed the same right to quality and continuous health care in accordance with his/her general state of health, the generally accepted professional standards and ethical principles, in the best interests of the patient and the respect of his/her personal views (paragraph 1). More specifically, the same law regulates the issue of the right for compensation of damages to the patient incurred due to a medical error. In this context, a provision of Article 31 is important, which stipulates that a patient who, due to a professional error of a health worker or health associate, in the implementation of health care suffers damage to his body, or a professional error causes the deterioration of his health, has the right for compensation under the general rules on liability for damages.

Negligent conduct of doctors due to which there has been a medical error can enter the incriminating zone of criminal offense "negligent provision of medical care" as in Article 251 of the Criminal Code of Serbia (The Criminal Code of Serbia, "Official Gazette of the Republic of Serbia", No 85/05-108/14). The perpetrator of this offense is a physician who in providing medical assistance applies obviously inappropriate means or an obviously inappropriate method of treatment, or does not apply the appropriate hygiene measures, or generally acts negligently and thus causes the deterioration of the health condition of a person (paragraph 1). Although different in content, the common denominator of the abovementioned actions is reflected in the unconscionable treatment of physicians when providing medical care, non-compliance with the adopted medical rules and common practices in the treatment of people, which gives "blanket" character to this offense (Lazarevic, 2011: 791).

In the group of criminal offenses against people's health (Chapter XXIII of the Criminal Code), there are other criminal offenses that criminalize improper treatment by physicians and other health workers, as following: unlawful conduct of medical experiments and trials (Article 252); failure to provide medical assistance (Article 253), and serious offenses against people's health (Article 259).

Finally, physicians can often make the following mistake: if they are not professional and competent for a specific problem; if they are not committed to the problem they are facing; if they are limited for time, or 
simply they have no time for more detailed consideration of problems (Vucetic et al., 2011: 107).

\section{Medical error in the court practice}

Medical error is a subject matter for the legal proceedings in which patients, as the injured party, claim compensation for damages. By the method of reviewing the situations in court practice, we can observe that the dominant legal proceedings are those in which moral and material satisfaction of the plaintiff is claimed. In this way, the subjective right to compensation given to individuals in their own interest in order to satisfy their own needs is ensured (Radisic, 2014: 18).

In order to enable the better understanding of the practical aspects of establishing medical error, we will highlight certain examples from the court practice. The legal proceedings result in total or partial adoption of the damage claims, or their dismissal due to improper reference to the damages incurred due to medical error.

The first case (Source: Judgement in Case No P 18. 3507/10):

Before the Basic Court in Kraljevo, legal proceedings were conducted for the compensation of damages of the plaintiff Jane Doe against the defendants: the Republic of Serbia, the Ministry of Health and the Health Center "Studenica", Kraljevo. Description consists in the fact that the plaintiff was admitted to the medical center for gynecological surgery on 26 March, 2010 and that day she underwent surgery via the laparoscopic method due to the existence of ovarian cysts. On the same day, after surgery, the plaintiff felt stomach pains and when she stood up, she noticed and felt a burn in the calf of her left leg. The next morning she saw a burn. She told that to the doctor but he did not react. Over the next few days, the wound was becoming more conspicuous, and began to be more painful. On 30 March, 2010, the plaintiff went to the regular check-up and bandaging, told the doctor how she felt, showed him the leg, the doctor then cleaned the wound with benosone and alcohol, and she went home. Over the next 3-4 times when she checked in for bandaging, the wound was disinfected, but the leg pain continued to intensify. After about two weeks, the plaintiff saw the surgeon, the wound was cleaned and she was instructed to go and see a plastic surgeon. The plastic surgeon performed the surgery under local anesthesia and put 13 stitches. The doctor, who had initially provided medical assistance to the plaintiff, declared that he hadn't been paying attention, and had not even notice that the plaintiff had had an injury on her leg before the operation, and that the plaintiff had not reported it to the doctor. He also 
stated that it was not clear how the plaintiff could have been burnt at all, and that he could only assume that perhaps the clasp, which had been located on the belt for binding patients during surgery to avoid patient's jerks, had come into contact with the plaintiff's leg. The doctor who subsequently performed plastic surgery on the plaintiff stated that the plaintiff had come to him with the burn that had the form of ellipsoid, and that she required surgical intervention in which dead tissue was removed.

Discussion: Having conducted the evidentiary proceedings, the court found that the claim was substantiated, accepted it and ordered the $\mathrm{HC}$ "Studenica" in Kraljevo to compensate for non-pecuniary damages to the plaintiff. The non-pecuniary damage is reflected in the physical pain suffered, the fear and the botched look. Summing up the findings and opinions of expert advisers and a neuropsychiatrist expert surgeon, the court found that the plaintiff based her claim on the principle of strict liability. The defendant referred to the application of Article 192 of the Law on Obligations (The Law on Obligations of Serbia, "Official Gazette of SFRY", No 29/78, Official Gazette of FRY, No 31/93, and Official Gazette of SMNE, No 1/03Constitutional Charter), which stipulate that the injured party who has contributed to the damage incurred or for it to be larger than it would otherwise be, is entitled to proportionately reduced amount of compensation. The Court did not accept the findings and opinion of expert advisers who advocated the divided responsibilities, as the plaintiff did not contribute to the occurrence of the injury by any of her actions whatsoever.

The second case (Source: Judgement, 12 P no. 1779/10):

Before the Basic Court in Kraljevo, civil proceedings for damages were conducted under the charges of John Doe against the defendant: HC "Studenica" in Kraljevo. Factual description is the following: the plaintiff was treated in the period from 7 January to 5 February, 2007 because of an injury to his left foot. The plaintiff states that "due to inadequate treatment and deterioration of health, he had to continue treatment at the Military Medical Academy in Belgrade, where he was operated and where the treatment was completed". He also states that due to health complications, the plaintiff suffered fear and pain of high intensity, which eventually weakened, and that during the period of treatment and recovery he was incapable of any work. The defendant disputed the allegations in the claim and pointed out the objection of shared responsibility (Article 192 of the Code of Obligations). Based on the medical records and the examination, the expert adviser was of the opinion that the treatment from the time of admission to the discharge had been in accordance with the rules of the profession, and that there had not been a failure which could be qualified as inadequate treatment which threatened the health of the plaintiff. The findings and 
opinion of the expert neuropsychiatrist stated that the plaintiff had not experienced primary fear at the time of the injury and treatment. There were no objections to the findings and opinions of expert advisers, so the court fully accepted them as professional, objective and sufficiently substantiated. On the basis of the reached facts, in evidentiary proceedings the court fully dismissed the plaintiff's claim.

Discussion: In this particular case, it is questionable whether there is a causal link between the physical pain, fear and mental anguish suffered by the plaintiff and the defendant's conduct, or whether the employees of the defendant and their irresponsible behavior caused the inadequate treatment. In this respect the opinion was derived by expert orthopedists, who found that doctors who treated the plaintiff, and who are employed by the defendant, acted according to the rules of the profession and that their conduct did not cause physical and mental suffering to the plaintiff. Such suffering was greatly increased by the plaintiff himself who contacted the doctor only after 9 days, and thus allowed the wound to further complicate and prolong the treatment time. This finding did not have any objections, so the court decided not to adopt the plaintiff's claim, which was based on the "existence" of medical error perpetrated by the employees of the defendant.

\section{Testing the physicians (course trainees) on the topic of medical error}

a) Type of research: This study was conducted as part of an accredited course entitled: "The process of determining professional liabilities in the cases of adverse outcomes of the medical treatment (medical error)". The course was approved by the Serbian Medical Chamber No 15302-1979/2014-01 of 18th August, 2014 (the course was recorded in the official records under the number: A-1-1801/14).

Testing of physicians was conducted in two cities and one municipality, namely: Kraljevo, Novi Pazar and Vrnjacka Banja. Before the beginning of the lectures, the trainees were given entry tests, and after the lectures they filled in exit tests (see Appendix 1).

b) Methods: When conducting the research, a broader methodological approach was used consisting of many different methods. As a method that dominated during the research we can mention the following: content analysis, statistical, historical, systematic, comparative, induction, deduction, etc.

c) Results: The Commission composed of three members discussed the results obtained from testing. On the basis of this, the results were 
Determining the legal liability in the cases of adverse outcomes of medical treatment...

analyzed using statistical methods. The final results are shown separately for each lecture.

Table 1. Results of testing the physicians in Vrnjacka Banja

\begin{tabular}{|c|c|c|c|c|c|c|c|c|c|c|c|c|}
\hline $\begin{array}{c}\text { Questi } \\
\text { on }\end{array}$ & 1 & 2 & 3 & 4 & 5 & 6 & 7 & 8 & 9 & 10 & 11 & 12 \\
\hline Entry & 56 & 36 & 50 & 42 & 82 & 10 & 22 & 12 & 6 & 4 & 10 & 4 \\
test & $\%$ & $\%$ & $\%$ & $\%$ & $\%$ & $\%$ & $\%$ & $\%$ & $\%$ & $\%$ & $\%$ & $\%$ \\
\hline Exit & 98 & 91 & 88 & 84 & 100 & 44 & 70 & 33 & 56 & 63 & 53 & 53 \\
test & $\%$ & $\%$ & $\%$ & $\%$ & $\%$ & $\%$ & $\%$ & $\%$ & $\%$ & $\%$ & $\%$ & $\%$ \\
\hline
\end{tabular}

Table 2. Results of testing the physicians in Kraljevo

\begin{tabular}{|c|c|c|c|c|c|c|c|c|c|c|c|c|}
\hline $\begin{array}{c}\text { Questi } \\
\text { on }\end{array}$ & 1 & 2 & 3 & 4 & 5 & 6 & 7 & 8 & 9 & 10 & 11 & 12 \\
\hline Entry & $\begin{array}{l}68 \\
0\end{array}$ & $\begin{array}{l}69 \\
0\end{array}$ & 28 & $\begin{array}{l}44 \\
0\end{array}$ & $\begin{array}{l}62 \\
0\end{array}$ & 13 & 68 & 85 & 15 & 22 & 18 & 44 \\
\hline test & $\%$ & $\%$ & $\%$ & $\%$ & $\%$ & $\%$ & $\%$ & $\%$ & $\%$ & $\%$ & $\%$ & $\%$ \\
\hline $\begin{array}{l}\text { Exit } \\
\text { test }\end{array}$ & $\begin{array}{l}99 \\
\%\end{array}$ & $\begin{array}{l}96 \\
\%\end{array}$ & $\begin{array}{l}79 \\
\%\end{array}$ & $\begin{array}{l}84 \\
\%\end{array}$ & $\begin{array}{c}100 \\
\%\end{array}$ & $\begin{array}{c}100 \\
\%\end{array}$ & $\begin{array}{l}92 \\
\%\end{array}$ & $\begin{array}{l}76 \\
\%\end{array}$ & $\begin{array}{l}72 \\
\%\end{array}$ & $\begin{array}{l}73 \\
\%\end{array}$ & $\begin{array}{l}77 \\
\%\end{array}$ & $\begin{array}{l}93 \\
\%\end{array}$ \\
\hline
\end{tabular}

Table 3. Results of testing the physicians in Novi Pazar

\begin{tabular}{|c|c|c|c|c|c|c|c|c|c|c|c|c|}
\hline $\begin{array}{c}\text { Questi } \\
\text { on }\end{array}$ & 1 & 2 & 3 & 4 & 5 & 6 & 7 & 8 & 9 & 10 & 11 & 12 \\
\hline Entry & 66 & 26 & 58 & 62 & 62 & 18 & 28 & 15 & 8 & 8 & 13 & 3 \\
test & $\%$ & $\%$ & $\%$ & $\%$ & $\%$ & $\%$ & $\%$ & $\%$ & $\%$ & $\%$ & $\%$ & $\%$ \\
\hline Exit & 99 & 95 & 83 & 87 & 100 & 64 & 90 & 36 & 52 & 73 & 57 & 63 \\
test & $\%$ & $\%$ & $\%$ & $\%$ & $\%$ & $\%$ & $\%$ & $\%$ & $\%$ & $\%$ & $\%$ & $\%$ \\
\hline
\end{tabular}

d) Discussion: Sublimating the shown results we can observe certain regularity in giving answers from the entry and exit tests.

Entry test: the highest number of respondents (percentage of $56 \%$, $68 \%$ and $66 \%$ ) correctly answered the first question (what is medical error?). The situation is similar with the answers to the fifth question $(82 \%$, $62 \%$ and $62 \%$ ), which consisted of the task of circling one of the offered answers to the following question: Serbia annually reports to OUN the following number of fatalities due to medical errors? The weakest answers were given to the tenth question (Which official actions are taken in preliminary proceedings related to a medical error?), and the twelfth question 
(List the relevant international and European legal instruments governing the right to health of man - the patient?). Expressed as a percentage is as follows, answers to the tenth question: $4 \%, 22 \%$ and $8 \%$, and answers to the twelfth question: $4 \%, 44 \%$ and $3 \%$.

Exit test: The percentage of the correct answers given here is not exactly the same as in the case with the entry tests. The percentage of the highest number of correct answers is to the first $(98 \%, 99 \%$ and $99 \%)$ and fifth $(100 \%, 100 \%$ and $100 \%)$ question, which is quite expected because the respondents previously demonstrated a high level of knowledge at the entry tests. The situation is somewhat different in other questions, because they exhibited different trends depending on the place of taking the tests. In Vrnjacka Banja, the lowest percentage of correct answers given to questions is to the sixth (44\%) and eighth (33\%) question. In Kraljevo and Novi Pazar, the lowest percentage of correct answers given to questions is to the eighth $(76 \%-36 \%)$ and ninth $(72 \%-52 \%)$ question.

The test results indicate the selective knowledge of physicians related to different aspects of medical error. They range from a complete knowledge of the concept and importance of medical error to weaker knowledge of the regulations governing the health care (Law on Health Care) and actions of physicians, thereby medical error becomes part of incriminating zone of certain criminal offenses against human health (Criminal Code). Finally, it is surprising that the question about tactical errors, which includes the optional selection of choices, did not receive a satisfactory answer in Vrnjacka Banja, while the situation in the other two cities was far more certain.

\section{Conclusion}

Providing medical assistance to patients carries with it the risk of mistreatment. This means the application of the procedures that are in violation to the applicable laws and bylaws governing the medical industry. However, what is necessary to be made first is the determination of the concept and importance of medical error. In this regard, we can note the presence of a number of different interpretations of medical treatment that represents a medical error in both the medical and legal terms (contra legem artis).

Determining the medical error in court practice is reflected in the legal proceedings in which plaintiffs (patients) require compensation for damages. Consideration of the substantiality of damage claims is largely conditioned by the results brought in by the medical expert advisers. Therefore, we can observe the different treatment of the court whose 
Determining the legal liability in the cases of adverse outcomes of medical treatment...

decisions range from full and partial acceptance or dismissal of damage claims. The circumstances that the court takes into account are various aspects of providing the medical assistance (act or failure to act).

The research of medical error within the course entitled "The process of determining the professional liabilities in the cases of adverse outcomes of the medical treatment (medical error)" included the entry and exit tests given to physicians. The results that were obtained showed that the level of knowledge demonstrated is greater when it comes to the area of health, and it is smaller when it comes to the field of legal regulations governing the medical industry. Particularly poor results can be observed in the sphere of knowledge of the procedural rules of the treatment.

\section{References}

1. Цветковић, М., Николић, Ђ. (2014). Грађанскоправна одговорност због непримене неопходних медицинских средстава. Зборник радова Правног факултета у Нишу, 53(68): 371-392.

2. Лапчевић, М., Иванковић, Д., Жигић, Д. (2001). Личност, здравље и здравствено васпитање. Секција опште медицине Српског лекарског друштва, Београд.

3. Радишић, J. (2004). Медицинско право. Факултет за пословно право, Београд.

4. Круљ, Љ. (2000). Одговорност лекара због необавештавања пацијента о ризицима операције - анализа једног случаја из праксе домаћих судова. Право - теорија и пракса, (3-4): 69-75.

5. Data were used from the following website: http://www.b92.net/zdravlje (15.06.2016.)

6. Радишић, J. (2009). Грађанска одговорност лекара која проистиче из њиховог занимања. Ревија за право осигурања, 7(1): 11-27.

7. Law on Health Care in Serbia ("Official Gazette of RS",No 107/05106/15)

8. Patients' Bill of Rights of Serbia ("Official Gazette of RS", No 45/13)

9. The Criminal Code of Serbia ("Official Gazette of RS", No 85/05108/14).

10. Лазаревић, Љ. (2011). Коментар Кривичног законика. Правни факултет Универзитета Унион, Београд.

11. Вучетић, Ч., Вукашиновић, 3., Тулић, Г., Дулић, Б., Димитријевић, К., Калезић, Н. (2011). Правни аспекти лекарске грешке. Acta chirurgica Iugoslavica, 58 (1): 107-111. 
12. Радишић, J. (2014). Правна квалификација медицински неиндикованог хируршког захвата обављеног на инсистирање пацијента. Зборник радова Правног факултета у Нишу, 58(66): 1328.

13. Judgement in Case P No $183507 / 10$

14. The Law on Obligations of Serbia ("Official Gazette of SFRY", No 29/78, Official Gazette of FRY, No 31/93, and Official Gazette of SMNE, No 1/03-Constitutional Charter").

15. Judgement in Case P No 12 1779/10

\section{Утврђивање правне одговорности код нежељеног исхода у лечењу (лекарска грешка)}

Anстракт: Позив здравственог радника (лекара) се састоји у пружағу здравствене помоћи пацијентима чиме се помаже санирању последица по ғихово нарушено здравствено стање. Позив лекара повезан је са многобројним ризицима којима су изложени сами радници и установе у којима се оваква помоћ пружа. Неретко се лекари суочавају односно бивају увучени у парничне поступке за накнаду претрпьене штете по основу наступања лекарске грешке. Зато је ииь ове студије анализа случајева у којима је дошло до лекарске грешке и начина утврђивања одговорности лекара. Подачи о случајевима лекарске грешке прикупљени су на основу непосредних искустава аутора рада који је као вештак учествовао у судским поступиима. Такође су прикупљени подаци добијени улазно/излазним тестовима лекара у оквиру истоименог Курса акредитованог од стране лекарске коморе. Прикупљени материјал је обрађен коришћењем више метода. Резултати су показали да непоштовање прочедуре на проактивном и реактивном нивоу доприноси настанку лекарске грешке. Томе у прилог иде и недовољна информисаност лекара о правним аспектима лекарске грешке. Ово истраживање је показало у којој мери лекарска грешка добија судски епилог. Такође се указује на недовољну информисаност лекара о правним аспектима лекарске грешке.

Кључне речи: лекарска грешка, паиијент, накнада итете, парнични поступак, имовинскоправни захтев, тестирање. 